\title{
The effect of topical knowledge on ESP learners' writing quality: complexity, accuracy, and fluency measures
}

\author{
Hussein Meihami - Naser Rashidi
}

DOI: 10.18355/XL.2018.11.04.05

\begin{abstract}
Practitioners of English for specific purposes (ESP) appraise the impact of different factors in writing quality of ESP learners. One of the least researched factors which seems to play an undeniable role in writing quality of ESP learners is topical knowledge. Given that, the purpose of this study is to investigate the effect of topical knowledge on writing quality of ESP learners in terms of complexity, accuracy, and fluency measures. To this end, 34 civil engineering students whose language proficiency was at upper-intermediate level and studied at the seventh semester of BA participated in this study. The participants were asked to write about a topic requiring general knowledge and the one demanding topical knowledge. A series of ANOVAs were run to analyze the writing quality of ESP learners, examining complexity, accuracy, and fluency measures. The results revealed that ESP learners produced more accurate and fluent writing productions when they wrote about the topic requiring topical knowledge. However, there was no statistically significant difference in the writing quality of ESP learners in terms of complexity measures when they wrote about general and topical prompts. The findings carry some implications for assessing and teaching writing skill in ESP context.
\end{abstract}

Key words: topical knowledge, writing quality, ESP learners, accuracy, fluency

\section{Introduction}

ESP learners are demanded by some forces impelling them to further their writing performance (Baynham, 2000). This may lead to a daunting feeling in ESP learners while they are trying to write in L2. This, according to Hyland (2013), is not due to students' lack of experience in L2 writing, but as a result of not being prepared for writing in an ESP context. The ESP conception of writing does not solely highlight the role of writing instruction as a generic skill but as a kind of competence in different genres. One of the factors posited by researchers as influential in ESP writing is topical knowledge (He, Shi, 2012; Leki, Cumming, Silva, 2008).

Topical knowledge is defined by Crandall and Tucker (1990) as the essential knowledge, either related to the content or academic subjects, which is specific to writing tasks or prompts. Douglas (2000, p. 46), moreover, believes that "background knowledge is a necessary integral part of the concept of specific purpose language ability." Considering schema theory as the theoretical underpinning of topical knowledge, McNeil (2010, p. 884) states that "background knowledge, understood as the content area knowledge or topic familiarity learners possess regarding texts." Bachman and Palmer's (1996) definition, furthermore, underscores the role of interaction in defining topical knowledge. They emphasize the interaction between topical knowledge and the ability to perform in the L2 context. According to Bachman and Palmer, the interaction between topical knowledge and real world make an L2 learner able to perform in L2 contexts.

The effect of topical knowledge on ESP learners' writing performance has been investigated in a number of studies (Ahmadi, Meihami, 2017; He, Shi, 2008, 2012; Kuiken, Vedder, 2007; O'loughlin, Wigglesworth, 2003). Before 2000, studies such as Tedick (1990), Spann (1990), and Jennings, Fox, Graves, and Shohamy (1999) explored the effect of topical knowledge on L2 learners' writing performance, obtaining different results. Moreover, after 2000, the fluctuating results of the studies

XLinguae, Volume 11 Issue 4, October 2018, ISSN 1337-8384, eISSN 2453-711X 
conducted by some researchers (e.g., Shi, 2001; He, 2010; He, Shi, 2012) justify the reason for doing further studies to address the effect of topical knowledge on ESP learners' writing quality. On top of this, the previous studies did not examine the effect of topical knowledge on ESP learners' writing quality. Furthermore, the previous studies in this realm did not that much pay attention to what the effects of topical knowledge could be on the ESP learners' writing quality development rather than their writing performance; as the former refers to the complexity, accuracy, and fluency of writing. The latter, however, highlights the writing components such as content, organization, and grammar.

Larsen-Freeman (1976) proposes an index of writing development in which writing quality includes complexity, accuracy, and fluency (CAF). Lu (2011) states that $\mathrm{CAF}$ can demonstrate a complete picture of language development in writing skill. Many studies have addressed CAF in general L2 writing when different methods and treatments have been used (Lu, 2011; Norris, Ortega, 2009; Ong, Zhang, 2011 Skehan, 2009; Tavakoli, Rezazadeh, 2014; Wigglesworth, Stortch, 2009). However, except for a dissertation by He (2010), not many studies focused on examining CAF in writing quality of ESP learners when addressing topical knowledge. Besides, the only mentioned study was done in an ESL context. That said, it can be a controversial issue that how ESP students who have topical knowledge of their field of study and at the same time they are in an EFL context write about the topics requiring their topical knowledge and the topics requiring their general knowledge.

The arguments mentioned above call for doing research highlighting the effect of topical knowledge on ESP learners' writing quality. Firstly, as important features of writing, complexity, fluency, and accuracy need to be investigated in writing quality of ESP learners when topical knowledge is considered. One may ask for the reason these indexes should be investigated when topical knowledge is the issue. One answer can be the fact that when assessing the writing quality and at the same time performance of ESP learners selecting the topic, either the general one or the one requiring topical knowledge, is utmost important for decision making (He \& Shi, 2012). This way the results from this study and the ones similar to it can help us in making a decision on whether the general topics are appropriate for the matter of assessing ESP learners' writing quality or topics requiring topical knowledge. Secondly, most of the previously conducted research in terms of topical knowledge and writing performance were done in an ESL context, suggesting more research to be done in an EFL context. Since the learners, in each of these contexts, are not in the exposure of L2 materials equally, there should be, doubtlessly, differences in the production of these learners. As the whole, the main purpose of this study is to investigate the effect of topical knowledge on Iranian ESP learners' writing quality in terms of complexity, accuracy, and fluency measures. This study, hence, addresses the following research questions:

1. Is there any statistically significant difference between the complexity measures of ESP learners' writings when they write about a general topic and a topic requiring topical knowledge?

2. Is there any statistically significant difference between the accuracy measures of ESP learners' writings when they write about a general topic and a topic requiring topical knowledge?

3. Is there any statistically significant difference between the fluency measures of ESP learners' writings when they write about a general topic and a topic requiring topical knowledge?

\section{Literature Review}

\section{Cognitive, sociocultural, and socio-cognitive theories of writing}

Three theoretical underpinnings are cited for L2 writing research and pedagogy (Tavakoli, Rezazadeh, 2014). Ortega (2009), among others like Hayes 
(1996) and Kellogg (1996), states that writing is a cognitively demanding, problemsolving, and recursive task which necessitates a process-based approach. A cognitive theory of writing highlights the role of the mind in L2 writing. The second underlying theory of writing research and pedagogy is a sociocultural one that does not consider writing as a network of processes which happens inside the mind. As Cumming (2001) believes, it considers writing as the offspring of co-construction of knowledge among various resources and contexts (Parks, 2000; Thatcher, 2000). Wigglesworth and Storch (2009) declare that this is a sociocultural theory to writing pedagogy and research which leads to research on the role of peer-interaction on writing. Unlike cognitive theory to writing pedagogy and research, sociocultural theory focuses on the role of social contexts on L2 writing.

Due to the nature of ESP pedagogy, L2 researchers and theorists, furthermore, try to combine these two theories to benefit from their advantages and eliminate their weaknesses (Cheng, 2010; Kobayashi, Rinnert, 2008; Sasaki, 2009). Tavakoli and Rezazadeh (2014) define writing in socio-cognitive theory as "a mental activity within a certain socially mediated context" (p. 87). Writing in an ESP context fits more with socio-cognitive theory. ESP learners, in different fields of study, have real audiences in the society whom they should consider while writing. They need to contemplate the social aspects of that society in their writing. Moreover, writing in an ESP context involves cognitive processes; notably the interaction between ESP learners' topical knowledge and their writing performance. Consequently, the cognitive aspects of writing need to be considered while addressing writing in an ESP context. This study benefited from a socio-cognitive theory of writing to address the purposes of the research. Hence, the participants of this study wrote about the topics which both addressed their real audiences in society or better to say their discourse community and their cognitive load. Cognitive load means that their topical knowledge was tapped upon.

\section{Writing Quality: Complexity, Accuracy, Fluency}

One important way to evaluate the quality of writing is by measuring the complexity, accuracy, and fluency of the texts written by L2 learners. In a corpus-based study examining the syntactic complexity of writing production of college-level English students, Lu (2011) declared that "a full picture of language development in L2 writing can only be obtained by engaging fluency, accuracy, and complexity measures at various linguistic levels, including vocabulary, morphology, syntax, semantics, pragmatics, and discourse" (p. 38). By focusing on these developmental indexes, one can reach a valid and reliable representation of L2 writing development. However, Perkins (1983) and Breiner-Sanders, Swender and Terry (2001) assert that these developmental measures cannot be interpreted as a valid measure of writing proficiency. This is so since writing proficiency is achieved through implementing rating scale designed for this purpose. Nevertheless, one can evaluate writing quality of L2 learners by measuring complexity, fluency, and accuracy (Tavakoli, Rezazadeh, 2014).

Although there were some slight differences among the measures of complexity, fluency, and accuracy used in different studies, many studies benefited from the same type of measures to assess L2 writing quality ( $\mathrm{Lu}, 2011)$. As the main building block of measuring complexity, fluency, and accuracy, one has to examine T-units, clauses, and number of words produced in a text (Foster, Skehan, 1996; Storch, 2005; Tavakoli, Rezazadeh, 2014). The most cited definition of T-unit is the one by Hunt (1970, p. 199) as "one main clause plus any subordinate clause or nonclausal structure that is attached to or embedded in it."

XLinguae, Volume 11 Issue 4, October 2018, ISSN 1337-8384, eISSN 2453-711X 


\section{Complexity Measure}

Wolfe-Quintero, Inagaki, and Kim (1989) reviewed 100 developmental measures used in 39 L2 writing developmental studies to capture the complexity, fluency, and accuracy of L2 writing. They came up with six measures for complexity investigated by Ortega (2003) among L2 writing studies at the college level. Ortega (2003) came up with five measures of complexity for measuring development in L2 writing. These five measures are the length of production, sentence complexity, subordination, coordination, and particular structures. In addition to that, Norris and Ortega (2009) mentioned three indexes for measuring syntactic complexity. They referred to each of them as an appropriate index for a specific level. They stated that for the beginning level, coordination is a suitable measure of complexity; while for intermediate and upper-intermediate proficiency levels, subordination is thought to be appropriate. Finally, at the advanced level, it is appropriate to use sub-clausal measure for identifying complexity. In this study, clause per T-units and dependent clause percentage was used as the measure of complexity.

\section{Accuracy Measure}

Wigglesworth and Storch (2009) propose two indicators of accuracy measure in L2 writing. One indicator is achieved by calculating the proportion of error-free T-units to all T-units. Additionally, another indicator of L2 writing accuracy is the proportion of error-free clauses to all clauses. In this study, the percentage of error-free T-units and the percentage of error-free clauses were computed to address the accuracy of ESP learners when they wrote about the general topic and the topic requiring topical knowledge.

\section{Fluency Measure}

Pilo (2001) defines writing fluency as the extent to which a piece of writing is native-like. Tarone, Downing, Cohen, Gillette, Murie, Dailey (1993, p. 170) define fluency as "nativeness, standardness, length, ease of reading, idiomaticity." Different researchers have used different measures to assess fluency of L2 writing (Tavakoli, Rezazadeh, 2014). For instance, Ong and Zhang (2011) examined fluency as the mean number of words per text; an average number of words per T-unit (Larson-freeman, 2006); and T-unit per text (Wigglesworth, Storch, 2009). In this study, the fluency of the L2 writing of ESP learners was measured by calculating the average number of words per text, T-unit per text, and clause per text. It seems that the three indexes can have a relationship with the topical knowledge of the ESP learners. The relationship can be due to the interaction between the topical knowledge of the ESP learners and their writing quality. Bachman and Palmer (1996) stated that topical knowledge could have an effect on writing performance of the learners. By sticking to this token, we can argue that topical knowledge of the ESP learners can lead to more accurate, more complex, and more fluent writing production since the interaction between topical knowledge and these indexes a productive one.

\section{Methodology \\ Participants}

The participants of this study were 34 students of civil engineering studying at a technical institute for engineering in Tehran, Iran. All of the participants were senior students, studying civil engineering at the seventh semester of their BA level. Of the total number of participants, 14 were female students and 20 were male students. The participants' age range was between 21 and 26, with an average of 22.8 years-of-age.

There were two concerns with regard to the sampling of this study. First of all, the English language proficiency level of the participants had to be measured. Since the purpose of this study was to investigate the effect of topical knowledge on 
writing quality of upper-intermediate students, a modular TOEFL test was administrated among 53 civil engineering students. Two sections of the modular TOEFL test, namely writing and reading were chosen as the proficiency test to obtain upper-intermediate students. After evaluating the results based on ETS (2014) scales, for both in reading and writing, 44 students were selected as upper-intermediate level.

The studies addressing the effect of topical knowledge on the performance of ESP students in different skills are criticized for not assessing ESP students' discipline knowledge (McNeil, 2011; Us'O-Juan, 2006). Even if the participants were at the same proficiency level of English, the difference in the topical knowledge they possess might have effects on the final results. To address this issue which could contaminate the results of this study, a knowledge test was designed and administrated among 44 participants whose English proficiency level was already specified as upper-intermediate. After consulting with experts in civil engineering, a knowledge test with ten items was designed as a pop-quiz by an instructor of civil engineering. The ten questions were about "Dam Construction," a technical course in civil engineering passed by all of the civil engineering students at seventh semester. The criterion for the participant selection was that each student who was able to answer eight out of ten questions was included as a participant in the study. The answers were evaluated by a civil engineering instructor. The results showed that only 34 students were able to answer eight out of ten questions. Finally, these 34 upper-intermediate students were selected to participate in the study.

\section{Data Collection Procedures}

Two different sessions were devoted to collect writing samples. In one session students were asked to write about a general topic addressing ESP learners' general knowledge. The topic was:

Some people believe that the best way of learning about life is by listening to the advice of family and friends, other people believe that the best way of learning about life is through personal experience. Compare the advantages of these two different ways of learning about life. Which one is preferable for you?

The participants were asked to write as much as they could about this topic. Since the rationale behind conducting this study was to obtain a measure of complexity, accuracy, and fluency of ESP learners' writing performance when they wrote about general and topical topics, there was no time and/or word limits.

In another session, the second topic assigned to address the effect of topical knowledge on ESP learners' writing quality. This time, by taking benefit from an expert instructor of civil engineering, an appropriate topic based on current discipline knowledge of the participants was assigned. The topic was:

Some civil engineers believe that the most important attention should be paid to topographical aspects of an area when a dam is constructed, other civil engineering emphasizes the role of materials to be used. Compares the two viewpoints. Which one do you prefer?

The participants were required to write as much as they could; it was the same as writing about a general topic, there were no time or word limits. This helped the reliability of the writing measurement and removed the interfering variable of heterogeneous topics to reach uncontaminated results. Consequently, the difference between the two topics was that the first one tapped upon the general knowledge of the participants while the second addressed their topical knowledge in their discipline.

\section{Data Analysis}

The main purpose of this study was to examine writing quality of ESP learners in terms of complexity, accuracy and fluency measures when they wrote about a general topic and a topic requiring disciplinary knowledge. In this regard, the writing productions of ESP learners were analyzed for complexity, accuracy, and

XLinguae, Volume 11 Issue 4, October 2018, ISSN 1337-8384, eISSN 2453-711X 
fluency with specific measures. For measuring the complexity of their writing productions, the proportion of clauses per T-units and percentage of dependent clauses to all clauses were calculated. The accuracy measures used in this study were the percentage of error-free T-units and the percentage of error-free clauses. Finally, to achieve the fluency of ESP learners writing productions the average number of words per text, the average number of T-units per text, and the average number dependent clauses per text were used.

Following studies such as those by Skehan and Foster (1997), Tavakoli and Rezazadeh (2014) and Yaun and Ellis (2004), the analyses of the dependent variable were conducted through separate ANOVAs. As Tavakoli and Rezazadeh (2014) state, each of the dependent variables has its own contribution to the quality of writing, necessitating a series of separate analysis of each dependent variable. In addition, by using separate sets of ANOVAs for the purpose of analyzing dependent variables helps reducing Type 1 error when the null hypothesis is rejected incorrectly (Yaun \& Ellis, 2004).

Rater subjectivity in assessing writing is a threat to the reliability of the analysis (Dunsmuir et al., 2015). To address this problem, the inter-rater reliability of the scores assigned by two raters was computed using Krippendorff's Alpha (KALPHA). The rationale behind this selection over other measurements was that KALPHA formula includes all other measurement types such as Cronbach Alpha, Cohens Kappa and Fleiss's Kappa (Deswert, 2012). The results of KALPHA showed a high index of reliability $(\mathrm{r}=.84)$ of the scores assigned by the two raters which can be interpreted with discussions and practices the raters had over the terms such as T-unit, dependent clause, and error-free productions before rating the ESP learner writing productions.

\section{Results}

This research probed the writing quality of Iranian upper-intermediate ESP learners in terms of three measures, namely complexity, accuracy, and fluency when ESP learners used their topical and general knowledge in their writing. The first research question was posed to investigate whether any statistically significant difference could be detected in the complexity measures of ESP learners' writings when they wrote about topical and general topics. The first one-way ANOVA was run to see the effect. Table (1) shows the results.

Table 1.

Results of ANOVA for complexity measures between topical and general topics

\begin{tabular}{|c|c|c|c|c|c|c|c|c|c|}
\hline $\begin{array}{c}\text { Indicato } \\
\mathrm{r} \text { of } \\
\text { Comple } \\
\text { xity } \\
\end{array}$ & Topics & $\mathrm{N}$ & Mean & $\begin{array}{l}\text { Std. } \\
\text { Deviation }\end{array}$ & Min. & Max. & $\mathrm{F}$ & Sig. & $\begin{array}{l}\text { Partial } \\
\text { Eta } \\
\text { Squared }\end{array}$ \\
\hline \multirow{3}{*}{ 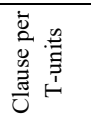 } & Topical & 34 & 2.50 & 1.10 & 1 & 4 & 2.03 & .164 & .042 \\
\hline & General & 34 & 2.08 & .92 & 1 & 4 & & & \\
\hline & Total & 68 & 2.29 & 1.03 & 1 & 4 & & & \\
\hline \multirow{3}{*}{ 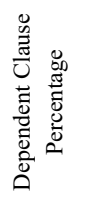 } & Topical & 34 & $\begin{array}{l}66.2 \\
5\end{array}$ & 16.62 & 35 & 95 & .264 & .610 & .006 \\
\hline & General & 34 & $\begin{array}{l}63.5 \\
0\end{array}$ & 20.28 & 28 & 95 & & & \\
\hline & Total & 68 & $\begin{array}{l}64.8 \\
7\end{array}$ & 18.40 & 28 & 95 & & & \\
\hline
\end{tabular}

The results of Table (1) indicate that the mean score of ESP learners' writing quality in terms of the two indicators of complexity, clause per T-units and dependent clause 
percentage, tend to be higher in topics requiring topical knowledge than the one requiring general knowledge $(\mathrm{M}=2.50,66.25$ and $\mathrm{M}=2.08,63.50$, respectively). However, Table (1) shows that the differences detected in the mean scores are not statistically significant (clause per T-units: $\mathrm{F}=2.03, \mathrm{df}=1, \mathrm{p}=.164$, Partial Eta Squared $=.042$, and dependent clause percentage: $\mathrm{F}=.264, \mathrm{df}=1, \mathrm{p}=.610$, Partial Eta Squared=.006). Overall, Table (1) indicates that there is not any statistically significant difference between a mean score of the writing quality of ESP learners in terms of complexity measures while they wrote about a topic addressing their topical knowledge and the one requiring their general knowledge.

The second research question probed whether any statistically significant difference could be detected with regard to the writing accuracy of ESP learners while they wrote about a topic requiring topical knowledge and a general one. To this end, two indicators of accuracy, namely error-free T-units and error-free clauses were examined in the topical and general writings of ESP learners. Table (2) shows the results of ANOVA addressing this research question.

Table 2.

\begin{tabular}{|c|c|c|c|c|c|c|c|c|c|}
\hline $\begin{array}{l}\text { Indicato } \\
\mathrm{r} \quad \text { of } \\
\text { Accurac } \\
y\end{array}$ & Topics & $\mathrm{N}$ & $\begin{array}{l}\text { Mea } \\
\mathrm{n}\end{array}$ & $\begin{array}{l}\text { Std. } \\
\text { Deviatio } \\
\mathrm{n}\end{array}$ & Min & Max & $\mathrm{F}$ & Sig & $\begin{array}{l}\text { Partial } \\
\text { Eta } \\
\text { Square } \\
\text { d }\end{array}$ \\
\hline \multirow{6}{*}{ 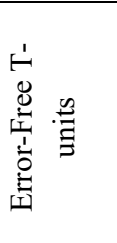 } & Topica & 3 & 19.5 & 7.74 & 5 & 35 & 14.9 & .00 & .245 \\
\hline & 1 & 4 & 4 & & & & 6 & 0 & \\
\hline & Gener & 3 & 12.0 & 5.40 & 2 & 25 & & & \\
\hline & al & 4 & 8 & & & & & & \\
\hline & Total & 6 & 15.8 & 7.60 & 2 & 35 & & & \\
\hline & & 8 & 1 & & & & & & \\
\hline \multirow{6}{*}{ 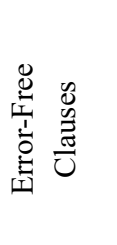 } & Topica & 3 & 41.8 & 12.07 & 21 & 69 & 4.97 & .03 & .098 \\
\hline & 1 & 4 & 3 & & & & & 1 & \\
\hline & Gener & 3 & 33.7 & 2.65 & 18 & 69 & & & \\
\hline & al & 4 & 5 & & & & & & \\
\hline & Total & 6 & 37.7 & 13.07 & 18 & 69 & & & \\
\hline & & 8 & 9 & & & & & & \\
\hline
\end{tabular}

Table (2) indicates that ESP learners achieve higher mean score when writing about the topic requiring topical knowledge in comparison to the general topic in the two indicators of accuracy: error-free T-units $(\mathrm{M}=19.54$ compared to $\mathrm{M}=12.08)$ and errorfree clauses $(M=41.83$ compared to $M=33.75)$. Table (2), moreover, shows that the difference in the mean score of the writing quality of ESP learners in terms of accuracy measure is statistically significant in both accuracy indicators (error-free Tunits: $\mathrm{F}=14.96, \mathrm{df}=1, \mathrm{p}=.000$, Partial Eta squared $=.245$, and error-free clauses: $\mathrm{F}=4.97, \mathrm{df}=1, \mathrm{p}=.03$, Partial Eta squared=.098). The effect size, calculated using partial eta squared, is .245 for error-free T-units which shows a high index of difference based on Cohen (1988). In addition, the effect size of error-free clauses is .098 which indicates higher than a moderate degree of significance. Overall, Table (2) shows that ESP learners performed more accurately when writing about the topic requiring their topical knowledge rather than the one with a general knowledge focus. The third research question was to investigate ESP learners' writing quality in terms of fluency measures when they wrote about the topic requiring topical knowledge and the one with general knowledge focus. To this end, three indicators of writing fluency,

XLinguae, Volume 11 Issue 4, October 2018, ISSN 1337-8384, eISSN 2453-711X 
namely word per text, T-unit per text, and clause per text were examined in the writings of ESP learners. Table (3) indicates the results of this examination.

Table 3.

\begin{tabular}{|c|c|c|c|c|c|c|c|c|c|}
\hline $\begin{array}{l}\text { Indicato } \\
\text { r of } \\
\text { Fluency }\end{array}$ & Topics & $\mathrm{N}$ & Mean & $\begin{array}{l}\text { Std. } \\
\text { Deviatio } \\
\mathrm{n}\end{array}$ & Min. & Max. & $\mathrm{F}$ & Sig. & $\begin{array}{l}\text { Partial } \\
\text { Eta } \\
\text { Square } \\
\text { d }\end{array}$ \\
\hline \multirow{3}{*}{ 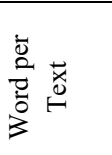 } & Topical & 34 & 292 & 91.14 & 120 & 450 & \multirow[t]{3}{*}{6.02} & \multirow[t]{3}{*}{.018} & \multirow[t]{3}{*}{.116} \\
\hline & $\begin{array}{l}\text { Genera } \\
1\end{array}$ & 34 & 230 & 83.89 & 120 & 420 & & & \\
\hline & Total & 68 & 261 & 92.16 & 120 & 450 & & & \\
\hline \multirow{3}{*}{ 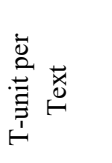 } & Topical & 34 & 33 & 10.21 & 10 & 50 & \multirow[t]{3}{*}{23.23} & \multirow[t]{3}{*}{.000} & \multirow[t]{3}{*}{.336} \\
\hline & $\begin{array}{l}\text { Genera } \\
1\end{array}$ & 34 & 20 & 8.11 & 9 & 38 & & & \\
\hline & Total & 68 & 26 & 11.19 & 9 & 50 & & & \\
\hline \multirow{3}{*}{ 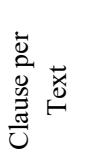 } & Topical & 34 & 72 & 15.92 & 45 & 98 & \multirow[t]{3}{*}{13.86} & \multirow[t]{3}{*}{.001} & \multirow[t]{3}{*}{.232} \\
\hline & $\begin{array}{l}\text { Genera } \\
1\end{array}$ & 34 & 54 & 15.78 & 35 & 95 & & & \\
\hline & Total & 68 & 63 & 17.89 & 35 & 98 & & & \\
\hline
\end{tabular}

As can be seen, Table (3) shows that the mean score of the word per text is higher when ESP learners wrote about the topic requiring topical knowledge $(M=292)$ in comparison to the topic addressing general knowledge of ESP learners $(\mathrm{M}=230)$. The results of one-way ANOVA, moreover, indicate that the mean score difference between the writing performance of ESP learners regarding the two topics is statistically significant $(\mathrm{F}=6.02, \mathrm{df}=1, \mathrm{p}=.018)$. The partial eta squared, also, shows that the effect size of the difference is high (Partial Eta Squared=.116) based on Cohen (1988). The second indicator of writing fluency, T-unit per text, shows the same tendency. It is clear from Table (3) that the number of T-units per text is higher $(M=33)$ when ESP learners wrote about topic requiring topical knowledge than the general one $(\mathrm{M}=20)$. Table (3) demonstrates that the mean score differences are statistically significant with a very high effect size $(\mathrm{F}=23.23, \mathrm{df}=1, \mathrm{p}=.000$, Partial Eta Squared $=.336$ ). Additionally, Table (3) indicates that clause per text, as one another indicator of fluency, has a higher mean score for the topic requiring topical knowledge $(\mathrm{M}=72)$ in comparison to the one addressing the general knowledge of ESP learners $(M=54)$. The results of one-way ANOVA show that the mean score difference between the performance of the ESP learners on the two topics with regard to clause per $\mathrm{T}$-unit is statistically significant $(\mathrm{F}=13.86, \mathrm{df}=1, \mathrm{p}=.001)$. Moreover, partial eta squared reported for this indicator of fluency shows a high index of difference (Partial Eta Squared= .232) based on Cohen (1988).

In a nutshell, the obtained results from Table (1, 2, and 3) show that the differences in ESP learners' writing quality in terms of accuracy and fluency measures are statistically significant when they wrote about the topic requiring topical knowledge and the one requiring general knowledge. However, no difference was detected in the complexity of writing quality of ESP learners regarding the two topics.

\section{Discussion}

This study examined the effect of topical knowledge on ESP learners' writing complexity, accuracy, and fluency. The first research question of this study was "Is 
there any statistically significant difference between the complexity measures of ESP learners' writings when they write about a general topic and a topic requiring topical knowledge?" The empirical evidence obtained by this research revealed that there was no statistically significant difference in the writing quality of ESP learners in terms of complexity measures when they wrote on either of topics (clause per T-units: $F=2.03$, $\mathrm{df}=1, \mathrm{p}=.164$, Partial Eta Squared $=.042$, and dependent clause percentage: $F=.264$, $\mathrm{df}=1, \mathrm{p}=.610$, Partial Eta Squared=.006). These results are compatible with the findings of Tavakoli and Rezazadeh (2014) and in contrast with Tuan and Storch (2007), although the purposes of these studies differ since those studies' focus was on general English, not ESP.

One possible explanation for not detecting any statistically significant results with regard to writing complexity of ESP learners on both topics can be given with the argument proposed by Biber, Gray, and Poonpon (2011) about the T-unit based measurement of complexity. In their critical evaluation of T-unit based measurement of grammatical complexity, Biber et al. (2011) posited that the T-unit based measurement lacks a strong linguistic theory and utility in testing application. It is thought that some of the complexity types of writing in this study were ignored due to the nature of the T-unit based measurement. Given that, Tavakoli and Rezazadeh (2014) declared "a need for more investigations exploring complex phrase constituents rather than clause constituents" (p. 99).

The second research question of this study was concerned with the effect of topical knowledge on ESP learners writing quality, focusing on the accuracy of their writing. The results (Table 2) indicated that topical knowledge of ESP learners had a constructive effect on their writing accuracy. It seems that topical knowledge raises ESP learners' awareness of their writing accuracy. Schmidt (1994) asserts that the induction of knowledge without awareness is not that much possible. The findings of our study revealed that the topical awareness of the students of civil engineering contributed to their accuracy awareness in their writing productions.

In addition, the interaction between ESP learners' topical knowledge and their L2 knowledge can be seen as another explanation for ESP learners' higher accuracy achievement with regard to the disciplinary topic. Some scholars (e.g., Nassaji, Tian, 2010; Swain, 1998; Swain, Lapkin, 1995) suggested that interaction can lead to accuracy in language productions. According to Bachman and Palmer (1996), the interaction between topical knowledge and other factors such as language knowledge and personal characteristics have an impact on language performance. By the same token, topical knowledge can be referred to as language use (Bachman \& Palmer, 1996). Since the ESP learners have greater interaction with topical knowledge than language knowledge this may help them to achieve a higher degree of writing accuracy. This is so since some of them lack this topical knowledge with regard to the general topic but all of them, due to the selection criterion, had topical knowledge about the topic requiring topical knowledge.

The third research question of this study was "Is there any statistically significant difference between the fluency measures of ESP learners' writings when they write about a general topic and a topic requiring topical knowledge?" The results of this study revealed that there was a statistically significant difference in the writing fluency of ESP learners when writing about a topic requiring topical knowledge and the one requiring general knowledge (Table 3). According to Dudley-Evens and St John (1998) ESP, learners use a text as a vehicle of information (TAVI) rather than as linguistic objectives (TALO). TAVI leads to better comprehension and finally more fluency. Since ESP learners have more engaged time with discipline related subjects, they will accrue rich topical knowledge which contributes to their fluency in their writing quality.

The results of this study, on the one hand, address the construct relevancy of topics in writing assessment (Messick, 1989). According to He and Shi (2012, p. 460)

XLinguae, Volume 11 Issue 4, October 2018, ISSN 1337-8384, eISSN 2453-711X 
"construct-irrelevance is a tangible threat to the validity of a test." The construct relevancy of the topic requiring topical knowledge of ESP learners was higher than the one requiring their general knowledge. The findings suggest that the higher accuracy and fluency achieved by the ESP learners when writing about the topic requiring topical knowledge are due to more construct relevancy of the topic for ESP learners. However, the topic requiring general knowledge of ESP learners, at the time of conducting this study when ESP learners were more engaged in their disciplinerelated subjects, was less construct relevant to them. It can also be another reason for less accuracy and fluency in ESP learners' writing productions requiring general knowledge.

The findings of the current study supported other studies that language proficiency is not the main and the only factor determining writing quality (He, 2010; He, Shi, 2012). In this regard, writing should not be considered as a skill which solely requires linguistics competence but a skill requiring discourse knowledge. Bachman and Palmer (1996) assert that discourse knowledge includes topical knowledge. He (2010) suggests that discourse knowledge, including topical knowledge, can enhance learners' understanding of writing to be aware of "complexities inherent in using language, including applying content or topical knowledge and accepting values in conflict with the discourses of which one is a member" (p. 158). When ESP learners write about a topic requiring topical knowledge, they make use of the discourse knowledge of their discipline, helping them to be more accurate and fluent in their writing productions in their disciplinary writing.

\section{Conclusions and Implications}

The purpose of this study was to investigate the effect of topical knowledge of ESP learners on their writing quality, namely complexity, accuracy, and fluency. To that end, writing quality of ESP learners was examined when they wrote about a general topic and a topical one. The findings of this study support the hypothesis that topical knowledge has a constructive effect on accuracy and fluency of ESP learners when they write about topics requiring their discipline-related knowledge, thus supporting the findings of previous studies reporting the positive effect of topical knowledge on L2 writing performance (He, 2010; He, Shi, 2012; Lee, Anderson, 2007; Tedick, 1990). The results revealed that the writing quality of ESP learners in terms of fluency and accuracy tended to be larger when ESP learners wrote about topics requiring topical knowledge.

The findings of this study bear some implications for assessing and teaching writing in ESP context. From one aspect, the results of this study, like the one conducted by He (2010), suggest that language test developers and teachers should pay attention to ESP learners' topical knowledge when choosing a topic to assess ESP learners writing performance. From another aspect, by the same token, language test developers and teachers need to consider ESP and EAP learners' L1 cultural background when selecting topics to assess their writing performance.

From a teaching perspective, the findings have implications with regard to implementing academic literacy acquisition (Block, 2003; Duff, 2007). Advocates of academic literacy acquisition emphasize exposing L2 learners to discourse knowledge of different disciplines to help them improve their L2 academic writing. Connecting discourse knowledge to the community of practice, L2 practitioners may help their L2 learners to write for a specific community. When L2 learners find an audience for their writing, they understand the related concepts better (Gunel, Hand, McDermott, 2009; Hohenshell, Hand, 2006). The fact that ESP learners have specific audiences for which they need to write may contribute to improving their writing. Owing to this, L2 teachers in general and ESP instructors, in particular, should pay attention to academic literacy acquisition of L2 learners to help them improve their L2 skills, particularly their writing skill. 
It is important to note that the findings of this study do not address the writing performance of ESP learners who are in different proficiency levels in terms of language and content. This limitation should be taken into account when the new methodology is designed for further research. In addition, other measurements of writing quality need to be used for future studies addressing the effect of topical knowledge of ESP learners on their writing quality. Notwithstanding its limitation, this study does suggest some insights into the effect of topical knowledge of ESP learners on their writing quality.

\section{Bibliographic references}

AHMADI, A. - MEIHAMI, H. 2017. The development of complexity, accuracy, and fluency in ESP learners' writing: A dynamic systems theory. XLinguae, vol. 10, n. 3, pp. 57-74. ISSN: 2453-711X

BACHMAN, L. - PALMER, A. 1996. Language testing in practice: Designing and developing useful language tests. Oxford: Oxford University Press. ISBN: 978 0194371483

BAYNHAM, M. 2000. Academic writing in new and emergent discipline areas. In M. LEA - B. STIERER (Eds.), Student writing in higher education: new contexts. (pp. 17-31). Buckingham: SRHE and Open University Press. ISBN: 9780335204083

BIBER, D. - GRAY, B. - POONPON, K. 2011. Should we use characteristics of conversation to measure grammatical complexity in L2 writing development? TESOL Quarterly, vol. 45, n. 1, pp. 5-35. ISSN:1545-7249

BLOCK, D. 2003. The social turn in second language acquisition. Georgetown, Washington, D.C.: Georgetown University Press. ISBN: 9780748615520

BREINER - SANDERS, K. E. - SWENDER, E. - TERRY, R. M. 2002. Preliminary Proficiency Guidelines. Foreign Language Annals, vol. 35, pp. 9-15. ISSN:1944-9720 CHENG, F. W. 2010. A Socio-cognitive Modeling Approach to Teaching English Argumentation. The Asian ESP Journal, vol. 6, n. 1, pp. 120-141. ISSN 2206-0979 COHEN, J. 1988. Statistical power analysis for the behavioral sciences. Hillsdale, NJ: Erlbaum.

CRANDALL, J. A. - TUCKER, G., R. 1990. Content-based language instruction in second and foreign languages. In S. ANIVAN (ed.), Language teaching methodology for the nineties, (pp.83-96). Singapore: SEAMEO Regional Language Centre. ISBN: 9971-74-036-2

CUMMING, A. 2001. Learning to write in a second language: Two decades of research. International Journal of English Studies, vol. 1, n. 2, pp. 1-23. ISSN: 19896131

DE SWERT, K. 2012. Calculating inter-coder reliability in media content analysis using Krippendorff's Alpha. Available online: http://www.polcomm.org/wpcontent/uploads/ICR01022012.pdf October, 30 ${ }^{\text {th }}, 2015$.

DOUGLAS, D. 2001. Three problems in testing language for specific purposes: Authenticity, specificity and inseparability. In C. ELDER - A. DAVIES (eds.) Experimenting with uncertainty (pp. 45-52). Cambridge: Cambridge University Press. ISBN: 9780521772549

DUDLEY-EVANS, A. - ST. JOHN, M., J. 1998. Developments in English for Specific Purposes. Cambridge University Press. ISBN: 9780521596756

DUFF, P. 2007. Second language socialization as sociocultural theory: Insights and issues. Language Teaching, vol. 40, n. 4, pp. 309-319. ISSN: 0261-4448

DUNSMUIR, S. - KYRIACOU, M. - BATUWITAGE, S. - HINSON, E. INGRAM, V. - O'SULLIVAN, S. 2015. An evaluation of the Writing Assessment Measure (WAM) for children's narrative writing. Assessing Writing, vol. 23, n. 1, pp. 1-18. ISSN: 1075-2935

XLinguae, Volume 11 Issue 4, October 2018, ISSN 1337-8384, eISSN 2453-711X 
FOSTER, P. - SKEHAN, P. 1999. The influence of source of planning and focus of planning on task-based performance. Language Teaching Research, vol. 3, n. 3, pp. 215-247. ISSN: 1362-1688

GUNEL, M. - HAND, B. - MCDERMOTT, M. 2009. Writing for different audiences: Effects on high school students' conceptual understanding of biology. Learning and Instruction, vol. 19, n. 4, pp. 354-367. ISSN: 0959-4752

HAYES, J. R. 1996. A new framework for understanding cognition and affect in writing. In C. M. LEVY \& S. RANSDELL (eds.). The science of writing (pp. 1-27). Mahwah, NJ: Erlbaum. ISBN: 9780805821086

HE, L. - SHI, L 2008. ESL students' perceptions and experiences of standardized English writing tests. Assessing writing. Assessing Writing, vol. 13, n. 1, pp. 130-149. ISSN: 1075-2935

HE, L. - SHI, L. 2012. Topical Knowledge and ESL Writing. Language Testing, vol. 29, n. 3, pp. 443-464. ISSN: 0265-5322

HE, L., 2010. The effect of topical knowledge on L2 writing. Electronic Theses and Dissertations. Available online: https://open.library.ubc.ca/cIRcle/collections/ubctheses/24/items/1.0071206

HOHENSHELL, L. M. - HAND, B. 2006. Writing-to-learn strategies in secondary school cell biology: A mixed method study. International Journal of Science Education, vol. 28, n. 2-3, pp. 261-289. ISSN: 0950-0693

HUNT, K., W. 1970. Do sentences in the second language grow like those in the first? TESOL Quarterly, vol. 4, n. 3, pp. 195-202. ISSN:1545-7249

HYLAND, K. 2013. ESP and Writing. In B. PALTRIDGE - S. STARFIELD (eds.), Handbook of English for Specific Purposes (pp. 95-114). Oxford: Blackwell. ISBN: 9780470655320

JENNINGS, M. - JANNA, F. - GRAVES, B. - SHOHAMY, E. 1999. The testtakers' choice: An investigation of the effect of topic on language-test performance. Language Testing, vol. 16, n. 4, pp. 426-456. ISSN: 0265-5322

KELLOGG, R., T. 1996. A model of working memory on writing. In C. M. LEVY \& S. RANSDELL (eds.). The science of writing (pp. 57-71). Mahwah, NJ: Erlbaum. ISBN: 9780805821086

KOBAYASHI, H. - RINNERT, C. 2008. Task response and text construction across L1 and L2 writing. Journal of Second Language Writing, vol. 17, n. 1, pp. 7-29. ISSN: $1873-1422$

KUIKEN, F. - VEDDER, I. 2007. Task complexity and measures of linguistic performance in L2 writing. International Review of Applied Linguistics in Language Teaching, vol. 45, n. 3, pp. 261-284. ISSN: 1613-4141

LARSEN-FREEMAN, D. 1976. Evidence of the need for a second language acquisition index of development. In W. Ritchie (ed.). Second language acquisition research: Issues and implications. New York: Academic Press. ISBN: 9780125895507 LARSEN-FREEMAN, D. 2006. The emergence of complexity, fluency, and accuracy in the oral and written production of five Chinese learners of English. Applied Linguistics, vol. 27, n. 4, pp. 590-619. ISSN: 0142-6001

LEE, H. - ANDERSON, C. 2007. Validity and topic generality of a writing performance test. Language Testing, vol. 24, n. 3, pp. 307-330. ISSN: 0265-5322

LEKI, I. - CUMMING, A. - SILVA, T. 2008. A Synthesis of Research on Second Language Writing. London: Routledge. ISBN: 9780203930250

LU, X. 2011. A Corpus-Based Evaluation of Syntactic Complexity Measures as Indices of College-Level ESL Writers' Language Development. TESOL Quarterly, vol. 45, n. 1, pp. 36-62. ISSN:1545-7249

MCNEIL, L. 2011. Investigating the contributions of background knowledge and reading comprehension strategies to L2 reading comprehension: an exploratory study. Reading and Writing, vol. 28, n. 2, pp. 883-902. ISSN: 0922-4777 
MESSICK, S. 1989.Validity. In R. L. LINN (ed.), Educational measurement (pp. 13103). New York: American Council on Education and Macmillan.

NASSAJI, H. - FOTOS, S. 2010. Teaching grammar in second language classrooms: Integrating form-focused instruction in communicative context. New York: Routledge, Taylor \& Francis Group. ISBN: 9780415802055

NORRIS, J. M. - ORTEGA, L. 2009. Towards an organic approach to investigating CAF in instructed SLA: The case of complexity. Applied Linguistics, vol. 30, n. 4, pp. 555-578. ISSN: 0142-6001

O'LOUGHLIN, K. - WIGGLESWORTH, G. 2003. Task design in IELTS academic writing task 1: The effect of quantity and manner of presentation of information on candidate writing. IELTS Research Reports, vol. 4, n. 1, pp. 89-131.

ONG, J. - ZHANG, L. J. 2011. Effects of task complexity on the fluency and lexical complexity in EFL students' argumentative writing. Journal of Second Language Writing, vol. 19, n. 4, pp. 218-233. ISSN: 1873-1422

ORTEGA, L. 2003. Syntactic complexity measures and their relationship to L2 proficiency: A research synthesis of college-level L2 writing. Applied Linguistics, vol. 24, n. 4, pp. 492-518. ISSN: 0142-6001

ORTEGA, L. 2009. Studying writing across EFL contexts: Looking back and moving forward. In R. M. MANCHON (ed.). Writing in foreign language contexts. Learning, teaching and research (pp. 232-255). Bristol: Multilingual Matters. ISBN: 9781847691835

PARKS, S. 2000. Professional Writing and the Role of Incidental Collaboration: Evidence from a Medical Setting. Journal of Second Language Writing, vol. 9, n. 2, pp. 101-122. ISSN: 1873-1422

PERKINS, K. 1983. On the use of composition scoring techniques, objective measures, and objective tests to evaluate ESL writing ability. TESOL Quarterly, vol. 17, n. 4, pp. 651-671. ISSN:1545-7249

POLIO, C. 2001. Research methodology in second language writing research: The case of textbased studies. In SILVA, T. \& P. K. MATSUDA (eds.): On Second Language Writing. Mahwah, NJ: Lawrence Erlbaum. ISBN: 9781501500282

SASAKI, M. 2009. Changes in English as a foreign language students' writing over 3.5 years: A sociocognitive account. In R. M. MANCHON (ed.), Writing in foreign language contexts. Learning, teaching and research (pp. 49-76). Bristol: Multilingual Matters. ISBN: 978-1847691835

SCHMIDT, R. 1994. Implicit learning and the cognitive unconscious: Of artificial grammars and SLA. In N. ELLIS (ed.), Implicit and explicit learning of languages (pp. 165-209). London: Academic Press. ISBN: 9789027268723

SHI, L. 2001. Native and nonnative speaking EFL teachers' evaluation of Chinese students' English writing. Language Testing, vol. 18, n. 3, pp. 303-325. ISSN: 02655322

SKEHAN, P. - FOSTER, P. 1997. Task type and task processing conditions as influences on foreign language performance. Language Teaching Research, vol. 1, n. 3, pp. 185-211. ISSN: 1362-1688

SKEHAN, P. 2009. Modeling second language performance: Integrating complexity, accuracy, fluency, and lexis. Applied Linguistics, vol. 30, n. 4, pp. 510-532. ISSN: 0142-6001

SPAAN, M. 1990. The effect of prompt in essay examinations. In C. C. DAN DOUGLAS (Ed.), A new decade of language testing research (pp. 98-122). Virginia, USA: Teachers of English to Speakers of Other Languages, Inc. ISBN: 9780939791439

STORCH, N. 2005. Collaborative writing: Product, process, and students' reflections. Journal of Second Language Writing, vol. 14, n. 3, pp. 153-173. ISSN: 1873-1422

XLinguae, Volume 11 Issue 4, October 2018, ISSN 1337-8384, eISSN 2453-711X 
SWAIN, M. 1998. Focus on form through conscious reflection. In C. DOUGHTY \& J. Williams (Eds.). Focus on form in classroom second language acquisition (pp. 6481). Cambridge: Cambridge University Press. ISBN: 9780521625517

SWAIN, M., - S. LAPKIN. 1995. Problems in output and the cognitive processes they generate: A step towards second language learning. Applied Linguistics, vol. 16, n. 3, pp. 370-391. ISSN: 0142-6001

TARONE, E. - DOWNING, B. - COHEN, A. - GILlETTE, S. - MURIE, R. DAILEY, B. 1993. The writing of Southeast Asian-American students in secondary school and university. Journal of Second Language Writing, vol. 2, n. 2, pp. 149-172. ISSN: 1873-1422

TAVAKOLI, M. - REZAZADEH, M. 2014. Individual and collaborative planning conditions: Effects on fluency, complexity and accuracy in L2 argumentative writing. The Journal of Teaching Language Skills, vol. 5, n. 4, pp. 85-110. ISSN: 2008-8189

TEDICK, D. J. 1990. ESL writing assessment: Subject-matter knowledge and its impact on performance. English for Specific Purposes, vol. 9, n. 1, pp. 123-143. ISSN: 0889-4906

THATCHER, B. L. 2000. L2 professional writing in a US and South American context. Journal of Second Language Writing, vol. 9, n. 1, pp. 41-69. ISSN: 18731422

TUAN, T. A. - STORCH, N. 2007. Investigating group planning in preparation for oral presentations in an EFL class in Vietnam. RELC Journal, vol. 38, n. 1, pp. 104124. ISSN: 0033-6882

US'O-JUAN, E. 2006. The compensatory nature of discipline-related knowledge and English-language proficiency in reading English for academic purposes. The Modern Language Journal, vol. 90, n. 2, pp. 210-227. ISSN: 0026-7902

WIGGLESWORTH, G. - STORCH, N. 2009. Pair versus individual writing: Effects on fluency, complexity and accuracy. Language Testing, vol. 26, n. 3, pp. 445-466. ISSN: 0265-5322

WOLFE-QUINTERO, K. - INAGAKI, K. S. - KIM, H.-Y. 1998. Second language development in writing: Measures of fluency, accuracy, and complexity. Honolulu, HI: University of Hawaii Press. ISBN: 9780824820695

YUAN, F. - ELLIS, R. 2003. The effects of pre-task planning and on-line planning on fluency, complexity and accuracy in L2 monologic oral production. Applied Linguistics, vol. 24, n. 1, pp. 1-27. ISSN: 0142-6001

Words: 7501

Characters: 49136 (27,30 standard page)

PhD Candidate in Applied Linguistics (TEFL), Hussein Meihami, Department of Foreign Languages and Linguistics,

Shiraz University, Iran

84334-71964, Shiraz University, Shiraz,

Iran

s.hmeihami@rose.shirazu.ac.ir

Professor of TEFL, Naser Rashidi,

Department of Foreign Languages and Linguistics, Shiraz University, Iran

Visiting Professor of University of California, Berkeley, USA,

84334-71964, Shiraz University, Shiraz,

Iran

nrashidi@rose.shirazu.ac.ir 